

\title{
Energy Justice at the End of the Wire: Enacting Community Energy and Equity in Wales
}

Submission for the Energy Policy Special Issue 'Exploring the Energy Justice Nexus'

Available at: $\underline{\text { https://doi.org/10.1016/j.enpol.2017.05.006 }}$

\author{
Alister Forman (corresponding author) \\ Sustainable Places Research Institute \\ Cardiff University \\ 33 Park Place \\ Cardiff, CF10 3BA
}

\section{FormanAK@cardiff.ac.uk}

\begin{abstract}
Energy justice has emerged as a useful lens for understanding and guiding energy decisionmaking. However, whilst calls for greater energy justice have grown, fleeting attention has been paid to the role and agency of the very people at the heart of this agenda. Clearly, given the increasing prevalence of local energy initiatives, such projects warrant more sustained focus both to explore how energy justice is constructed between settings and to prompt greater consideration of its associated outcomes. This paper seeks to address this gap by using energy justice to assess local ownership of small scale energy generation through a study of the community energy sector in Wales. In so doing, it aids greater understanding of the energy equity dimension, understood in terms of accessibility and affordability, of the energy trilemma. From a conceptual standpoint, the research examines how energy justice is negotiated and contested at community-scale through a focus on issues of distributive and procedural justice. From a policy standpoint, the research shows that community energy is often involved in a wide range of local objectives and directs attention to how best to support such initiatives to further stimulate local action and deliver more widespread equity gains.
\end{abstract}

\section{Keywords}

Energy justice; Wales; community energy; equity; energy ownership; energy transitions 


\section{Introduction}

Energy justice has much to offer in helping to understand the complex trade-offs involved in the making of energy policy as expressed through the competing demands of energy security, energy equity and environmental sustainability - jointly known as the energy trilemma (Gunningham, 2013; World Energy Council, 2015; Heffron et al, 2015). With roots in environmental justice and climate justice (Walker, 2012; Schlosberg and Collins, 2014), energy justice has quickly gained traction and provides a critical perspective on issues of production and consumption across whole energy systems (Goldthau and Sovacool, 2012; McCauley et al, 2013; Bickerstaff et al, 2013; Sovacool et al, 2014; Sovacool and Dworkin, 2014; Jones et al, 2015). Across much of this agenda is an unashamedly normative bias for an energy-just world that 'equitably shares both the benefits and burdens involved in the production and consumption of energy services, as well as one that is fair in how it treats people and communities in energy decision-making' (Sovacool and Dworkin, 2014: 5). Energy justice thus places renewed emphasis on the 'human dimensions' often marginalised in research into energy studies and global environmental change (Schlosberg, 2004; Sovacool, 2014; Castree et al, 2014).

In this paper, I follow this approach by using energy justice to assess local ownership of small scale energy generation through a study of the community energy sector in Wales. The study aids greater understanding of the energy equity dimension, defined in terms of accessibility and affordability (World Energy Council, 2015), of the energy trilemma. This is achieved by examining local ownership as one aspect of accessibility. For therein lies the rub: energy justice scholarship has, for the largest part, paid limited attention to the ways in which people and communities might contribute towards an energy-just future from the ground-up. Whilst 
there is a long history of research that examines local participation in large-scale energy decision-making (Wynne, 1982; Davies, 1984; Kraft and Clary, 1991; Morton et al, 2009), this blind-spot neglects potentially 'important insights into how alternative forms of what might constitute "energy justice" are being established" (Fuller and Bulkeley, 2013: 70) through more local and community-based engagements with our energy systems (Smith, 2012). After all, there is no shortage of such projects, including: community energy schemes (Walker et al, 2007; Walker and Devine-Wright, 2008; Hoffman and High-Pippert, 2010; Jeong et al, 2012; Devine-Wright and Wiersma, 2013; Strachan et al, 2015), low-carbon communities (Heiskanen et al, 2010; Middlemiss and Parrish, 2010), and the Transition Town movement (Hopkins, 2008; Aiken, 2012; Seyfang and Haxeltine, 2012; Grossmann and Creamer, 2017). This virtual absence of a bottom-up perspective risks diminishing the role of energy-using publics to one of consultation as mere recipients of energy justice; reifying the position of already privileged actors (Catney et al, 2013) and impeding scholarship from understanding the ways in which multiple justice perspectives may combine to achieve broadly similar goals (Cowell, 2016a; Markantoni, 2016).

Picking up Bickerstaff et al's (2013:7) claim that 'an energy justice agenda is, at present, only partially articulated', I argue for greater attention to the diverse and particular forms given to energy justices constructed in situ (Eden, 2017). This perspective inverts the conventional view in centralised energy systems of the space and people at the end of the transmission wire as simply the end-point of a system of flows and currents, providing scope for energy justice to be implemented at both ends of the wire. Such analyses not only can reveal new insights into the concept itself but also unlock potential for more nuanced policy measures to enhance energy justice and help balance the energy trilemma. 
To develop the analysis, I use Sovacool and Dworkin's (2014) distinction between 'top-down' and 'bottom-up' approaches for the enactment of energy justice. Found in organization theory, enactment is used to denote reflection and action on the environment in order to change it (Nicholson, 1995; Weick, 2009). I apply this framework through the lens of community energy, using data gathered over a twelve-month period of research in the sector in Wales, linking insights from both the 'triumvirate of tenets' (McCauley et al, 2013; Jenkins et al, 2016b) and the energy justice decision-making framework (Sovacool et al, 2016). From a conceptual standpoint, the research examines how energy justice is negotiated and contested at community-scale through a focus on issues of distributive and procedural justice. From a policy standpoint, the research emphasises the ways in which community energy is often involved in a wide range of local objectives and directs attention to how best to support such initiatives to further stimulate local action and deliver more widespread equity gains.

\section{Theoretical Context}

\subsection{Unpacking Energy Justice}

Energy justice research seeks to offer a basis for guiding action with respect to energy decision-making for policy-makers and practitioners in order to 'provide all individuals, across all areas, with safe, affordable and sustainable energy' (McCauley et al, 2013: 107). Studies in energy justice thus complement research on energy transitions (Geels, 2002; Meadowcroft, 2009), the ongoing nature of which remain fairly weakly understood (Späth and Rohracher, 2012). These include issues across the whole energy system, such as: the politics of energy extraction and production (Butler and Simmons, 2013; McCauley et al, 2016; Sovacool and Scarpaci, 2016; Jenkins et al, 2016a; Yenetti and Day, 2016; Yenetti et al, 2016), energy 
consumption (Hall, 2013; Hards, 2013; Shirani et al, 2013; Walker et al, 2016; Chatterton et al, 2016); Simcock and Mullen, 2016), fuel poverty (Sovacool, 2015; Chard and Walker, 2016; Day et al, 2016; Bednar et al, 2017), health (Liddell et al, 2016), and energy system governance (Goldthau and Sovacool, 2012; Heffron and McCauley, 2014). Such work aids understanding of how principles of justice, equity and fairness might be embedded in the context of energy system change, whilst also addressing the adverse impacts of already existing patterns of energy production and consumption (Eames and Hunt, 2013; Newell and Mulvaney, 2013). Energy justice thus aims to understand, reshape and resolve the externalities linked to energy systems and energy practices. Such aims seek to minimise distribution of energy-related costs, maximise benefits, identify strategies for sharing benefits and burdens in a fair way, and ensure that energy decision-making is representative and consistent with due process, particularly with respect to vulnerable and marginalised groups (Bickerstaff et al, 2013; McCauley et al, 2013; Sovacool and Dworkin, 2014; Sovacool et al, 2016).

A central development of the field has been the emergence of a range of complementary frameworks to identify energy injustice(s) and guide energy decision-making. Three particular approaches have gained traction: (a) the repackaging of the classic trivalent approach of environmental justice (Schlosberg, 2004), under the auspices of the 'triumvirate of tenets' of distributional, procedural, and recognition justice (McCauley et al, 2013), to address energy-related issues across the whole energy system (Hammond and Pearson, 2013; Jenkins et al, 2016b), (b) a decision-making framework in the form of a range of eight principles - availability, affordability, due process, transparency and accountability, sustainability, intragenerational equity, intergenerational equity, and responsibility - to be applied by decision-makers to energy-related problems (Sovacool and Dworkin, 2015; 
Sovacool et al, 2016), and (c) an Energy Justice Metric adding a quantitative component to measure energy justice in order to engage more effectively with an energy policy-making environment perceived as dominated by economic logics (Heffron et al, 2015).

Within each approach, responsibilities for enacting energy justice are spread across a broad understanding of decision-makers as the more traditional notion of policymakers and regulators, but also ordinary students, jurists, homeowners, businesspersons, investors and consumers' (Sovacool et al, 2016: 1). Whilst this view accepts the potential of action on energy justice across a range of scales, in practice decision-makers higher up the tree are often privileged within such frameworks ${ }^{1}$. This issue limits the relevance of such approaches for energy-using publics to negotiate energy justice on their own terms and for privileged actors to enable them to do so through tailored policy-making. Thus, whilst it remains important to keep in view distinctions between frameworks developed for the purpose of critical analysis and those developed to aid decision makers in taking actions, it is nonetheless arguable that existing frameworks are less useful to actors at meso- and micro- scales and provide only partial scope for understanding and capturing the full range of ways in which energy systems - and the broader economies, societies, and lifestyles they support and underpin - might be made more just in practice. Indeed, as Chilvers and Longhurst (2016) and Walker et al (2016) have recently shown, opening-up and extending understandings of

\footnotetext{
1 As one example, the 'Contemporary Applications' of the decision-making framework (Sovacool et al, 2016: 5) highlight such processes as UNFCC with respect to responsibility, the United Nations Sustainable Energy for All initiative with respect to intragenerational equity, and The Extractive Industries Transparency Initiative with respect to transparency and accountability - each highly valuable and relevant within their particular contexts but offering only partial scope for guiding or facilitating efforts to advance energy justice at meso- and micro- scales.
} 
participation with respect to energy decision-making and knowledge production, beyond mere consultative approaches, have a crucial part to play within the context of a just energy transition.

In what follows, the relevance of a more open perspective on the enactment of energy justice is discussed. There is a need for such an approach to aid greater understanding of the interaction, politics and contestation of energy justice solutions in particular settings and across the whole energy system.

\subsection{Enacting Energy Justice}

Interventions in the energy system are not restricted to the 'corridors of power' alone. As Heffron and McCauley (2014: 437) point out: 'energy justice is concerned with social responsibility by the private sector, the government and the public'. This view accepts space for research to engage with the various ways in which energy justice is enacted by actors across a range of scales. A more helpful starting point in this regard can be found in Sovacool and Dworkin's (2014: 358) call for the 'necessity of comprehensive action'. In this view, 'Regulators, policymakers, and parliamentarians can implement [energy justice solutions] ... from the "top-down", whereas individuals, families, and companies can implement others from the "bottom-up"' (Sovacool and Dworkin, 2014: 358). For government, these may include policies to facilitate renewable, distributed or community energy generation strategies (DECC, 2013; 2014); for the private sector, the embedding of a whole-systems perspective within their approach to corporate social responsibility (Meadows, 2009; Jenkins et al, 2016b; Smith, 2016) or divestment from fossil fuels (Ayling and Gunningham, 2015; Bratman et al, 2016); whilst, for the public, such action may involve expanding 'energy 
citizenship' (Devine-Wright, 2006) or creating grassroots sustainable energy innovations (Seyfang et al, 2014).

In addition to extending normative ideals in refined lists of justice principles, new insights into how to balance the competing demands of the energy trilemma can be gained through attention to 'the diverse sites at which social actors are already and continuously engaged in sustainable energy transitions' (Chilvers and Longhurst, 2016: 588, emphasis in original). The notion of enactment, drawn from organization theory, is useful here in that it denotes a process of reflection and action on the environment in order to change it (Nicholson, 1995; Weick, 2009). Enactment thus provides a lens for understanding how normative ideals of justice are shaped into particular solutions in particular contexts. Indeed, enactment recognises the importance of actors choosing specific courses of action and that the 'circumstances people confront are malleable and multiple, rather than monolithic and singular' (Weick, 2009: 195) creating possibilities for distinct energy justice outcomes between places and aiding insight into the politics and contestation of energy justice in practice. A key feature of this perspective is that idealised, normative accounts of energy justice are actively decoded and given meaning by actors operating in particular contexts. In other words, context matters for how justice is articulated in practice (Simcock, 2014). From an enactment perspective, justice is not detached from the particular settings in which it is negotiated as though it can be readily transposed from pre-given categories and normative principles. In this view, justice is an ongoing process that is - to borrow from Chilvers and Longhurst (2016: 602) - always 'in the making'. 
To date, there has been a lack of critical interrogation of how energy justice is enacted through bottom-up pathways. Fuller and Bulkeley (2013) offer one of few contributions to suggest an active role for 'low carbon communities' in enacting energy justice. More recently, Fuller and McCauley (2016) explore the strategic framing of energy justice from the stance of activism and advocacy, albeit still at a level of abstraction from publics. This gap risks obscuring actions on the ground in the localised, particular places where ... power and injustice are known, experienced and resisted' (Schlosberg, 2004: 534) as local 'decisionmakers', even taking an expansive view of the term, are effectively relegated to consultative roles conferred by arbitrarily narrow interpretations of procedural justice and participation (Misa, 1994; Chilvers and Kearnes, 2015; Chilvers et al, 2015; Walker et al, 2016). As such, I invite you to consider locating energy justice at the end of the wire; where people, families, communities, and societies work and struggle daily to realise energy justice on their own terms.

The following section outlines community energy as a form of activity consistent with a more bottom-up approach to the enactment of energy justice ${ }^{2}$, that has been variously associated with claims of justice-promoting potential that have largely remained untested in the literature to date.

\subsection{Community Energy as Enacting Energy Justice}

\footnotetext{
${ }^{2}$ In practice, projects may be more or less bottom-up based on how they are developed, recognising the diverse nature of the sector and that the 'specific spatial configuration of any specific project will vary' (Devine-Wright and Wiersma, 2013: 1112).
} 
Community energy has grown in both academic and policy discourse over the last decade as a feature of policy strategies and local movements promoting small-scale, decentralised and diversely owned models of renewable energy generation (Walker et al, 2007; Walker and Devine-Wright, 2008; Hoffman and High-Pippert, 2010; Devine-Wright and Wiersma, 2013). Following Van Veelen and Haggett (2016), community energy is regarded as: (a) exhibiting a scalar character consistent with meso-level developments (Walker and Cass, 2007; DevineWright and Wiersma, 2013), (b) involving local participation in the project and in the allocation of benefits (Walker and Devine-Wright, 2008), and (c) a model of more locally appropriate development, expressing diverse sets of values, that ensures greater sensitivity to local context and improved acceptability within host communities (Walker et al, 2007; Hielscher et al, 2011; see also: Demski et al, 2015). Whilst the literature on community, decentralised and distributed energy has burgeoned alongside its growing relevance in policy in recent years, its provenance extends from more established literatures on appropriate technology (Dunn, 1978) and small-scale development (Schuhmacher, 1974), and evokes strong comparisons with the 'soft path' of Lovins (1977) influential energy paths framework.

This is a crucial point from the perspective of energy justice, as Sovacool et al (2014: 85, emphasis added) stress that an 'equitable distribution of energy services will only be accomplished by the development of a new global energy system that is based ... on renewable sources ... and distributed generation'. Further still, community energy is increasingly linked with a wide range of benefits, including: sustainable income streams, fuel poverty alleviation, skills development, promoting social cohesion, addressing inequalities, enhancing equity, community regeneration, and building autonomy (Hargreaves et al, 2013; Wiersma and Devine-Wright, 2014; Callaghan and Williams, 2016; Van Veelen, 2017). Such outcomes 
remind us of the central nature of energy to life in contemporary society and the difficulties involved in separating energy out fully from wider aims in particular settings in view of its role as a supporting system. Thus, as a form of 'soft' energy path development displaying a diverse range of benefits with potentially widespread justice affects, and as a test-bed for tracing the ways in which public values and notions of (energy) justice are enrolled in the context of energy system change, community energy is situated as both an expression of and an arena for the enactment of energy justice, negotiated at a more local scale than has hitherto been addressed.

The energy justice dimensions and implications of community energy form the focus of the following empirical sections, using the case of community energy in Wales, studied during fieldwork over a twelve-month period from December 2014. The methodology is first outlined, before presenting results and discussion, and ending with concluding remarks and policy recommendations.

\section{Methodology}

\subsection{Field Setting}

Between 2010 and 2015, community energy in Wales was developed mainly through the Ynni'r Fro programme, the Welsh Government's former flagship support policy for community renewable energy schemes. Ynni'r Fro was the outcome of joint funding between the Welsh Government and the European Regional Development Fund (ERDF). A requirement for ERDF funding was an explicit focus on the themes of enhancing equal opportunities and environmental sustainability (Welsh Government, 2016a). Such requirements ensured that, although not explicitly, from the very start Ynni'r Fro emphasised the role of community- 
owned and developed energy generation as a tool for achieving a broad range of social, environmental, and economic objectives; placing energy centre-stage in supporting the wider well-being of people and communities. Indeed, support for community energy by the Welsh Government is part of a broader package of policies in Wales that place a legal obligation on public sector bodies to commit to sustainable development across all aspects of policy and service delivery, which is unique in the United Kingdom. These actions are outlined in the Well-being of Future Generations (Wales) Act 2015, which highlights the integrated nature of social, economic, environmental and cultural well-being (Welsh Government, 2015), and deems installed capacity of renewables one of a number of indicators relevant for achieving such aims (Welsh Government, 2016b). Support for community energy is thus perceived to contribute towards commitments to increasing community cohesion, prosperity, resilience and responsibility (Welsh Government, 2016a), with Ynni'r Fro aiding 112 groups over its lifetime and 47 'pipeline projects' in receipt of funding and advisory support to meet these aims.

Whilst Ynni'r Fro has clearly been important in aiding the development of the community energy sector in Wales, the structure of the programme and nature of support offered ensured that growth was largely driven from the bottom-up with communities in the driving seat. 'Preparatory grants' of up to $£ 30,000$ were offered to fund projects in their early stages. However, conflict with European State Aid regulations ${ }^{3}$, shortly after the launch of Ynni'r Fro, structured how grants could be spent and hampered greater financial support by the Welsh

\footnotetext{
${ }^{3}$ Preventing public authorities from potentially distorting competition and trade within the EU by using taxpayer-funded resources to confer advantage on bodies in receipt of funding.
} 
Government for the sector. Communities were largely faced with the task of raising often vast sums of capital finance for their projects on their own with some advisory and informal support from across the emerging sector. In addition, the fact that Ynni'r Fro outlined no explicit requirements as to how revenues raised through projects should be spent allowed a diverse and vibrant collection of local actors to combine under the banner of community energy whilst aiding broader integrated objectives outlined in the Well-being of Future Generations (Wales) Act. In these ways, Ynni'r Fro assisted in nurturing a budding sector, enabling it to grow as a primarily bottom-up movement responding to local needs, and further enabling analysis of the implications of a wider perspective on agency for the enactment of energy justice on the ground.

\subsection{Data Collection and Analysis}

This research employed a broadly interpretive and constructivist approach, with an intensiveextensive research design (Sayer, 1992) aiding a thorough picture of the community energy sector in Wales. The extensive phase involved compiling and interviewing a database of key actors, including community energy project leaders, as well as further stakeholders (e.g. project members, policymakers, local authorities, developers) identified through snowball sampling ${ }^{4}\left(O^{\prime}\right.$ Leary, 2004). Interview guides addressed the 'triumvirate of tenets' (McCauley et al, 2013) of energy justice, fixing on justice issues linked to distributive, procedural and recognition justice in the questions asked as well as accounts framed in justice terms within broader questions on community energy and the local setting. This enabled an energy justice

\footnotetext{
4 'Project leaders' were identified through access to Welsh Government data whilst 'project members' refers to participants who held a voluntary role in a project, subscribed to a membership organisation attached to a project, or bought shares in a project (or any combination of these).
} 
perspective to be assembled across the fieldwork and analysis, through examination of community energy project benefits and their distribution as well as participation across the wider community in each case.

The intensive phase involved participatory workshops in host communities, using a participatory action research-inspired (Kemmis and McTaggart, 2005) approach, and examined distributive outcomes of projects in order to assist in the design of community benefit strategies. In addition, follow-up interviews with participants and participant observations were carried out where possible to complement the workshops. Projects in the intensive sample were derived from the extensive phase; with the latter used as an opportunity for 'casing the field' (Ragin, 1992). Three projects were selected using case selection criteria developed by Miles and Huberman (1994; see also: Curtis et al, 2000) with the aim to include projects from each of north, south, and mid- Wales to ensure a sample representative of the Welsh context.

In sum, 51 in-depth, semi-structured interviews ${ }^{5}$ with 28 community energy project leaders (developing 33 separate schemes), 9 project members, and 14 stakeholders were carried out, alongside 3 half-day participatory workshops with 18 participants across all three groups. Interviews and workshops were audio-recorded, transcribed and analysed thematically (Braun and Clarke, 2006) using NVivo qualitative analysis software. Coding was theoretically driven, reflecting the interest in issues of distributive, procedural, and recognition justice. On the one hand, questions addressed whether or not community energy enhanced energy

\footnotetext{
${ }^{5} 42$ in the extensive phase and 9 to complement participatory workshops in the intensive phase.
} 
justice from the standpoint of distribution, revealing the complexity involved in delivering such outcomes and wide-ranging approaches to doing so. On the other hand, questions centred on if and how community energy projects aided greater participation in the energy system, with implications particularly for procedural justice. These issues are addressed in the following sections.

\section{Results and Discussion}

\subsection{Community Energy and Distributive Justice}

Distributive justice has long been considered an aspect of energy infrastructure siting, prompting discussions around the provision of benefits to communities as a tool for managing siting conflicts (Cowell et al, 2011). Whilst such benefits often take the form of a fund paid by developers to locally impacted communities, this study shows the extent to which distributive justice in the context of community energy is viewed by participants in diverse and complex ways that vary from place-to-place. For many projects, such views are poorly captured by simple transfer payments. As one project organiser in Neath Port Talbot shared:

The fact that we have a hydro scheme on that river would be very nice, the sustainable income would be a benefit thank you very much, but let's see if we can't add value to that, make it a demonstration model, try and create some jobs out of it being part of a wider research project, see if we can't get some of the locals trained up to maintain it, see if we can't get some locals trained up to be tourist guides... It all sort of has an additional life to it that adds to the community benefit (Project Organiser, Neath Port Talbot). 
Whilst some projects thus prioritised attributes such as local skills and employment, further variations were evidenced in projects seeking to protect the Welsh language and pursue cultural activities such as supporting local festivals. Such aspirations provide links to identity and justice as recognition (Heller, 2003; Honneth, 1995) as well as an emergent view of community energy as culture. Indeed, such views suggest connections between place identity and the active support and use of community energy project benefits as a form of place-protective action (Devine-Wright, 2009). As one project organiser on the Isle of Anglesey noted:

we've got some cultural issues here because we've got the Welsh language and we'd identified that we would also like to sustain that if we could ... [so] an active project which would ... have recognised that the language had a principal place in our project would also have been a very positive development (Project Organiser, Isle of Anglesey).

A further feature that was evidenced widely across Wales was the responsiveness of projects to declining local services and public sector cuts. In this view, community energy contributes towards meeting local needs in a UK context characterised overwhelmingly by austerity at the time fieldwork took place. Mixed views were often expressed regarding whether projects should focus on providing added benefits, rather than stepping into prop-up local services widely considered the function of local authorities. However, a number of projects also saw such openings as providing significant opportunities to build momentum, rescale responsibility and meet local needs more effectively. As one project organiser in Pembrokeshire outlined: 
I mean the passion of a lot of things that have happened in that area and in that particular village have been driven by the closure of the primary school, so things like that I think have really spurred people on to want to take ownership over facilities and activities really, and I think declining services more laterally are probably an extra motivation ... In cuts and just all of those problems you can, to some extent, protect yourself against those if you take responsibility for and ownership of those assets and those services... (Project Organiser, Pembrokeshire).

Projects interviewed during this research overwhelmingly conceptualised 'distribution' and 'benefit' in such wide-ranging terms. More established social, economic and even cultural rationales were thus frequently mobilised as primary aims, extending understandings of their role as drivers for community energy and as issues of justice at community-scale. Indeed, the energy infrastructures envisaged and created were often viewed highly instrumentally:

half the money goes to support a community café and the other half of the money goes to support childcare provision, which means that you've got a certain number of people who are getting subsidised childcare place, they can then access work, they bring money back into the community, whether they spend that on insulation on the house or not (Project Adviser, Rhondda Cynon Taf).

As the foregoing analysis suggests, energy justice in the context of community energy becomes bound up with issues such as local development, local culture and the local 
economy, and the benefits envisaged often extend well beyond energy-based goals. Indeed, the variation in outcomes between projects emphasises the extent to which benefits are often tailored and responsive to local needs. In addition, such outcomes highlight the ways in which normative ideals of justice are mediated and contextualised in particular places through processes of enactment and emphasises the conjoined nature of energy, as a supporting system, with wider justice issues on the ground.

Of course, community energy also embodies concerns with more traditional energy justice issues relevant from the perspective of distributive justice. Indeed, a recurring theme emphasised by projects was the ambition to be able to supply energy locally, thereby addressing issues of 'availability' and 'affordability' within the energy justice decision-making framework (Sovacool et al, 2016):

I think the holy grail is being able to sell electricity, I think that would be a game changer and I think if we can sell electricity cheaper and cleaner than the current grid situation we could take on a vast percentage of ... [the local] population (Project Organiser, Carmarthenshire).

Entitlement to cheaper energy across local communities through renewables development is a long-standing aspiration (Cowell et al, 2011) but has become a more prominent issue in response to the inability of communities to realise more conventional energy benefits through local project development. This point is exemplified by intermediary body Community Energy Wales recently adopting a 'right to local supply' as part of its manifesto (Community Energy Wales, 2015). In this way, the expansion of community energy has 
rendered the lack of local ability to access energy even more stark than under existing centralised arrangements since, despite increased spatial proximity to energy generating infrastructure, communities are effectively compelled to sell the energy they produce back to the grid through the foreclosure of realistic alternatives:

\author{
it is possible in theory to set up, as it were, a company to market your electricity \\ to individuals ... [but] at the moment it's quite a challenge to do that for a small \\ project (Project Organiser, Pembrokeshire).
}

Whilst the UK energy market regulator Ofgem has created a pathway for distributed generators to supply energy through 'Licence Lite' provisions (Ofgem, 2015), the additional complexities such arrangements pose for small groups in terms of finances and group capacities are significant barriers for communities attempting to deliver already technically challenging projects (Malhotra, 2006). Indeed, confrontation with inhospitable regulatory environs and conflicting policy regimes directly impact the ability of community energy projects to deliver more widespread benefits in conventional energy terms.

Such tensions highlight the politics and contestation involved in fostering greater energy justice, emphasising issues such as energy justice for whom, on whose terms, and under which circumstances. Indeed, the failure of existing policy regimes to facilitate ambitions towards local supply reflects the current lack of alignment between top-down and bottomup approaches to produce more progressive energy justice outcomes. A further wellrehearsed debate in this regard relates to the conflict between communities of interest and communities of place (Walker, 2008), which was evidenced in this study through the 
widespread reliance of projects on share offers to raise development capital. Indeed, as one board member for a project in Gwynedd noted: 'You don't want to export the benefit'. Such concerns emphasise the widely held view of projects involved in this study that the vast majority of benefits ought to remain local in order to offset financial benefits transferred through share ownership. More broadly, the emergence of such conflicts highlight the difficulties involved in constructing a pure form of energy justice and suggests a need for careful attention to context with respect to how energy justice is negotiated in practice.

Returning to the aims of this paper, the analysis supports the view that attention to the situated actions of local actors reveals a broad perspective on distribution in the context of energy justice, moving beyond issues such as infrastructure siting to address integrated aspects of well-being and local needs. In this way, 'social and cultural contexts emerge as central to governing how and why communities become involved with environmental action' (Dunkley and Franklin, 2017: 120) and the enactment of energy justice (see also: Marres, 2007). Whilst there remains a need to maintain a critical perspective on particular projects, community energy in Wales has brought, or is poised to provide, benefits to local communities in social, economic, cultural and environmental terms and it is difficult to untangle the integral role of energy from wider justice issues experienced within communities. Indeed, the analysis highlights the ways in which a multi-scalar conception of energy justice, supported by a wider view of agency, allows actors at different scales to 'work with different understandings of the spatiality of the issues at hand' (Walker, 2009: 630). Problems persist for communities to deliver more widespread conventional energy benefits, such as increasing availability and affordability, through aspirations towards local energy supply. Such conflicts indicate ongoing policy and regulatory incongruences that must be 
squared if the spectrum of opportunities for enhancing energy justice through community energy are to be fully captured.

\subsection{Community Energy and Procedural Justice}

Issues of procedure in the context of energy justice are typically concerned with access to energy decision-making, highlighting the ways in which communities are engaged in such processes (Jenkins et al, 2016b) alongside ensuring 'due process' and 'transparency and accountability' (Sovacool et al, 2016). From the standpoint of community energy this study raises a number of issues in this regard, whereby (a) energy justice is actively negotiated by participants, representing local interests, in interaction with formal institutional processes (such as planning), and (b) projects are tasked with ensuring that their aims and objectives are reflective of the communities they claim to represent.

Taking the first of these issues, each of the communities involved in this study had interactions with public bodies as part of the decision-making process for consenting and licensing. This is particularly relevant in the context of this research in view of the fact that one important reading of procedural justice relates to the 'fair and equitable institutional processes of a state' (Schlosberg, 2007: 25). A precursor for the growth of community energy in this regard relies on projects being approved through the planning regime as the institutional arbiter of procedural justice. Indeed, planning was a regular theme in discussions with both community energy projects and stakeholders throughout the study and concerns were frequently raised with respect to whether community energy projects were given a fair hearing in the planning process: 
Not many [planning authorities] seem to understand what a community project is, they're still much more familiar with private developments (Project Organiser, Neath Port Talbot).

we've been trying to read our visual impact assessment and it's another language really, it's so scientific... so we submit it, and we submit it and the planning officer goes 'oh no I disagree'. So whilst they say that it's scientific and technical, it's also subjective, so that's been a real massive problem (Project Organiser, Pembrokeshire).

Such concerns are problematic from the standpoint of procedural justice, and particularly 'transparency and accountability' and 'due process' within the energy justice decision-making framework (Sovacool et al, 2016). Indeed, the foregoing issues raised by projects indicate that procedural justice priorities, such as clarity and availability of information as well as equality of access and respect for participants (Walker, 2012), were clearly undermined with regard to lack of transparency in how information is used and assessed in decision-making and through inequality of respect for non-traditional business models such as community energy.

Planning in particular was, by Welsh Government's own admission, highlighted in the Ynni'r Fro final evaluation as 'a significant, possibly the most significant, barrier reported to projects progressing' (Welsh Government, 2016a: 68). This is perhaps most evident in the seemingly casual approach taken by local planning authorities to guidance aimed at giving weight in the 
planning process to the sorts of social and economic benefits community energy projects are poised to provide. As officials from Welsh Government and Community Energy Wales noted:

our planning colleagues... [have] spent a lot of time and effort and energy on developing, writing and drafting sensible planning guidance through the technical advice notes and planning policy ... that actually if you read it you think this is so sensible, what's not to like? That then goes to the local authority and they interpret it differently, in a way that you think 'why'? (Government Official, Welsh Government).

to be fair to Welsh Government, they have actually sent out clarifications ... to local authorities to try and make sure that they do take into account the social and economic benefits of community schemes, but it's just very sketchy acrossthe-board how that's interpreted... and different planning officers interpret it in different ways (Organisation Official, Community Energy Wales).

As the above quotes indicate, both stakeholders and wider project representatives interviewed during this study pointed towards the role of local planning authorities in preventing the wider spread of community energy project benefits. Indeed, the suggestion that local planning authorities interpreted guidance from Welsh Government inconsistently and contrary to its objectives emphasises the extent to which community energy is simply not institutionalised across the public sector in Wales. This is all the more surprising in a country with a statutory obligation for public sector bodies to commit to sustainable development, and subverts expectations that community-owned projects will have fewer problems 
obtaining planning permission (Walker, 2008). Perhaps most significantly, such issues seriously undermine both fairness and equality of respect within the planning process for community energy as a vehicle for energy development more broadly. As one project organiser in Powys noted:

[The project has] a huge community social and economic component to it, that accords with the ministerial statements in support of community energy schemes, and at the end of the day the local authority... refused to consider the material benefits of the community energy scheme, and its social and economic benefits, and brought it down solely to a matter of environmental impact and visuals (Project Organiser, Powys).

Whilst without doubt achieving due process can be long and arduous for the very reason that it is careful and systematic, such conflicts highlight the need from a policy perspective to ensure the alignment of energy justice aims across scales at an early stage ${ }^{6}$ if community energies are not to be squandered (see also: Parkhill et al, 2015). Indeed, the example illustrates the ways in which the pursuit of more radical sustainable energy pathways, underpinned by decentralised and participatory developments such as community energy, are disrupted by concurrent moves to extend entitlements on behalf of incumbent largescale, centralised developers ${ }^{7}$ and conflicting policy regimes (Strachan et al, 2015; Cowell et al, 2016; Cowell, 2016b). In addition, such attitudes further emphasise the conflicting politics

\footnotetext{
${ }^{6}$ A ministerial intervention directed at local planning authorities following the Ynni'r Fro midterm evaluation was deemed ineffective at defusing this 'intractable' issue (Welsh Government, 2016a).

${ }^{7}$ Particularly relevant in Wales given proposals for new nuclear power at Wylfa Newydd on the Isle of Anglesey.
} 
and contestation associated with the realisation of energy justice in practice and highlights a need for greater openness within policy structures with respect to opportunities and vehicles through which energy justice might be enacted on the ground.

Alongside such institutional perspectives on procedural justice, community energy projects also face a more informal challenge to ensure that their aims and objectives are truly reflective of the communities on whose behalf they operate. Given that this article has already demonstrated that community energy is often responsive to determinations of local need this issue carries significant weight. In view of the early stage of development of many of the projects receiving support through Ynni'r Fro, future research with a more substantive group of energy projects post-construction would be beneficial on this point. However, a range of perspectives were offered by communities that already had generating infrastructure or were likely to achieve it. Issues raised included doubts about the processes through which community consensus could be negotiated. As one project organiser in Powys noted:

Obviously, sheerly from a mechanical perspective, you can't have a hundred and sixty members of the community acting as committee members as part of the project; it needs to be rationalised and it needs to be kept to a manageable amount of people (Project Board Member, Powys).

Whilst it is undoubtedly difficult to entirely eliminate such procedural dilemmas, perhaps more surprisingly was the clear potential for deeper conflicts between project leaders and wider communities to emerge with respect to project objectives. Such tensions were evident 
across a number of projects involved in this study, as illustrated by the following quotations from project organisers:

I mean I really genuinely do want to make sure that the community are empowered to apply for this and that it's representative of them ... that it's fair and open but ... you've got to draw a line somewhere (Project Organiser, Pembrokeshire).

It feels important to give people an option to own the company ... It feels important to give that but then, in a strategic sense, it feels like perhaps it ought to be driven a bit more by the project (Project Organiser, Swansea).

Such evaluations again emphasise the contested nature of energy justice and suggest tensions between desires to extend participatory governance in energy infrastructure at a local scale with potential loss of control of projects by the people at the forefront of delivering them. Indeed, whilst most projects in Wales appear genuinely to strive for inclusivity, real struggles were evidenced in some communities with respect to managing the delicate balance between projects established in the name of the community with the associated ambitions of the people ultimately responsible for making those projects happen. With respect to the aims of this paper, this analysis highlights scope for community energy to extend energy justice in terms of rescaling decision-making to local communities. At the same time, however, it is important to remember that "there are many contrasting visions of what "justice" can involve in any given context' (Simcock, 2016: 475) extending to aspects of both distribution and procedure. There is a need therefore to maintain a critical perspective on the 
representativeness of projects established in the name of the community (see also: Johnson and Hall, 2014; Grossman and Creamer, 2017) in order to ensure that associated distributions, and the processes through which they are underpinned, remain locally relevant particularly given the considerable lifespan of such initiatives.

\section{Conclusions and Policy Recommendations}

This paper demonstrates how energy system interventions at more local scales have the capacity to foster greater energy justice. It contributes insights into distribution and procedure in community energy ownership, as one aspect of accessibility, in the equity arm of the energy trilemma. In so doing, new perspectives on how to address the competing demands of energy security, energy equity and environmental sustainability are encouraged. Indeed, the analysis illustrates overlaps between community energy and issues of local development, local environment, local economy, local culture and social justice and highlights the varied and contextually-specific nature of energy justice outcomes between places. Such outcomes include, but often extend well beyond, simple energy-based goals and suggest that community energy ownership has much to offer in engendering more widespread equity gains. As recent policy approaches in the United Kingdom under Electricity Market Reform ${ }^{8}$ have tended to prioritise affordability over ownership as a means to enhance equity, the analysis suggests that there is much scope to capitalise on a wider equity dividend through a more diverse approach to ownership in UK energy policy. More broadly, the research

\footnotetext{
${ }^{8}$ Further detail on Electricity Market Reform available: https://www.ofgem.gov.uk/electricity/wholesale-market/market-efficiency-review-andreform/electricity-market-reform-emr
} 
highlights the value of an energy justice perspective for understanding and addressing energy policy issues.

Equally as important are the insights this paper reveals into the politics and contestation of energy justice, emphasising issues such as energy justice for whom, on whose terms, and under which circumstances. By focussing on bottom-up perspectives, this paper addresses an empirical gap in the audience and actors to which energy justice has mainly been directed. Indeed, the analysis illustrates the ways in which energy justice can be enacted beyond the 'corridors of power' through initiatives such as community energy and, in so doing, highlights problems with an understanding of energy justice only as a benefit that is bestowed upon society from the top-down. This is not to suggest that local action will always be positive (Marvin and Guy, 1997; Catney et al, 2014) and the analysis emphasises the diverse nature of community energy itself (Devine-Wright and Wiersma, 2013) that demands a critical perspective with respect to issues of process and outcome. However, a key feature of this research has been to show that context matters for how energy justice is enacted within settings. In this view, energy justice is emplaced, situated and realised in diverse ways depending on context. This fact raises wider questions about the ontological status of justice and warns against an understanding of the concept that marginalises alternative visions of how energy justice might look in practice. Indeed, as energy justice scholars, care must be taken not to reify perspectives of industry and policy elites at the expense of those experiencing injustice on the ground. Instead, as the inability of communities to deliver on ambitions for local supply suggests, future efforts ought to focus on building consensus and opportunities for action between scales if greater energy justice is to be realised in practice. 
As a final reflection, these findings have relevance for each of the five challenges (Jenkins et al, 2017) outlined in this Special Issue. In learning from national policy contexts, Jenkins et al (2017: 632) question 'how contextually-specific our strategies for energy justice must be'. Whilst future research might further verify this point, evidence from the study in Wales suggests that context is indeed key and that strategies for achieving energy justice both exceed energy-based goals and are often tailored to reflect local circumstances. Indeed, these findings highlight the importance of using methodologies for energy justice that are sensitive to context and able to account for the wide range of views held in particular settings. In legal and regulatory context, the analysis showed that the strong desire for community energy projects to be able to provide energy locally is hindered through conflict with the regulatory regime governing energy supply in the UK. Such conflicts highlight the contestation of energy justice and the need for greater thinking across energy types in order to more effectively accommodate both centralised and distributed generation options. Finally, the challenge of temporal approaches is especially relevant to community energy, given that research in this area is ultimately in its infancy considered against the lifespan of the energy infrastructures created. Such concerns include vigilance about the extent to which community energy projects remain locally-relevant over time, as well as identifying where and when added value can be conveyed. More broadly, community energy creates temporal questions of justice extending to issues of decommissioning, landscape restoration and, beyond, what the next stage of the energy transition involves for the communities who come to depend on the local energy infrastructures increasingly being created. 


\section{Disclosure Statement}

This research was conducted as part of a three-year PhD award collaboratively funded by the Economic and Social Research Council (Grant Number: ES/J500197/1) and Welsh Government. Whilst the Welsh Government partly funded this research, the views are those of the author, are independent of Government, and do not reflect or constitute Government policy.

\section{Acknowledgements}

I am indebted to Richard Cowell, Ria Dunkley and Alex Franklin for helpful discussions and comments on earlier drafts of this paper and the development of this research. Thanks as well to four anonymous reviewers, Rich Gorman and participants at the 'Exploring the Energy Justice Nexus' sessions at RGS Annual Conference 2016, London and the $3^{\text {rd }}$ Energy and Society Conference 2016 in Leipzig, Germany for their engagement with earlier drafts of this paper. Special thanks to all participants across Wales who donated their precious time to be involved in this research. 


\section{References}

1. Aiken, G. (2012) 'Community Transitions to Low Carbon Futures in the Transition Town Network (TTN)' In: Geography Compass 6 (2) 89 - 99

2. Ayling, J. and Gunningham, N. (2015) 'Non-state Governance and Climate Policy: The Fossil Fuel Divestment Movement' In: Climate Policy

doi:10.1080/14693062.2015.1094729

3. Bednar, D. J., Reames, T. G. and Keoleian, G. A. (2017) 'The intersection of energy and justice: Modeling the spatial, racial/ethnic and socioeconomic patterns of urban residential heating consumption and efficiency in Detroit, Michigan' In: Energy and Buildings 143 (2017) $25-34$

4. Bickerstaff, K., Walker, G. and Bulkeley, H. (2013) 'Introduction: Making Sense of Energy Justice' In: Bickerstaff, K., Walker, G. and Bulkeley, H. (eds) Energy Justice in a Changing Climate: Social Equity and Low-Carbon Energy London: Zed Books

5. Bratman, E., Brunette, K., Shelly, D. C. and Nicholson, S. (2016) 'Justice is the Goal: Divestment as Climate Change Resistance' In: Journal of Environmental Studies and Sciences 6 (4) $677-690$

6. Braun, V. and Clarke, V. (2006) 'Using Thematic Analysis in Psychology' In: Qualitative Research in Psychology 3 (2) $77-101$

7. Butler, C. and Simmons, P. (2013) 'Framing Energy Justice in the UK: The Nuclear Case' In: Bickerstaff, K., Walker, G. and Bulkeley, H. (eds) Energy Justice in a Changing Climate: Social Equity and Low-Carbon Energy London: Zed Books

8. Callaghan G, and Williams, D. (2016) 'Teddy bears and Tigers: How Renewable Energy can Revitalise Local Communities' In: Local Economy 29 (6-7) 657 - 674

9. Catney, P., Dobson, A., Hall, S. M., Hards, S., MacGregor, S., Robinson, Z., Ormerod, M. and Ross, S. (2013) 'Community Knowledge Networks: An Action-orientated Approach to Energy Research' In: Local Environment 18 (4) 506 - 520

10. Catney, P., MacGregor, S., Dobson, A., Hall, S. M., Royston, S., Robinson, Z., Ormerod, M. and Ross, S. (2014) 'Big Society, Little Justice? Community Renewable Energy and the Politics of Localism' In: Local Environment 19 (7) $715-730$

11. Castree, N., Adams, W. M., Barry, J., Brockington, D., Büscher, B., Corbera, E., Demeritt, D., Duffy, R., Felt, U., Neves, K., Newell, P., Pellizonni, L., Rigby, K., Robbins, P., Robin, L., Bird Rose, D., Ross, A., Schlosberg, D., Sörlin, S., West, P., Whitehead, M. and Wynne, B. (2014) 'Changing the Intellectual Climate' In: Nature Climate Change 4 (September 2014) $763-768$ 
12. Chard, R. and Walker, G. (2016) 'Living with fuel poverty in older age: Coping strategies and their problematic implications' In: Energy Research and Social Science 18 (August 2016) $62-70$

13. Chatterton, T J., Anable, J., Barnes, J. and Yeboah, G. (2016) 'Mapping Household Direct Energy Consumption in the United Kingdom to Provide a New Perspective on Energy Justice' In: Energy Research and Social Science 18 (2016) $71-87$

14. Chilvers, J. and Kearnes, M. (eds) (2015) Remaking Participation: Science, Environment and Emergent Publics London: Routledge

15. Chilvers, J., Pallett, H. and Hargreaves, T. (2015) Rethinking Energy Participation as Relational and Systemic [Online] Available: www.ukerc.ac.uk/asset/C7DA3C2E-16834FC8-9F7127F1C275D993/ [Accessed 23 September 2016]

16. Chilvers, J. and Longhurst, N. (2016) 'Participation in Transition(s): Reconceiving Public Engagements in Energy Transitions as Co-Produced, Emergent and Diverse' In: Journal of Environmental Policy and Planning 18 (5) $585-607$

17. Community Energy Wales (2015) Community Energy Wales Manifesto [Online] Available: http://communityenergywales.org.uk/community-energy-wales-manifesto/ [Accessed: 01 December 2016]

18. Cowell, R., Bristow, G. and Munday. M. (2011) 'Acceptance, Acceptability and Environmental Justice - The Role of Community Benefits in Wind Farm Development' In: Journal of Environmental Planning and Management 54 (4) $539-557$

19. Cowell, R. (2016a) 'Global Energy Justice: Problems, Principles, and Practices' In: Journal of Environmental Policy and Planning 18 (2) $253-255$

20. Cowell, R. (2016b) 'Decentralising Energy Governance? Wales, Devolution and the Politics of Energy Infrastructure Decision-Making' In: Environment and Planning C doi: $10.1177 / 0263774 \times 16629443$

21. Cowell, R., Ellis, G., Sherry-Brennan, F., Strachan, P. A. and Toke, D. (2016) 'Energy Transitions, Sub-national Government and Regime Flexibility: How has Devolution in the United Kingdom affected Renewable Energy Development?' In: Energy Research and Social Science dx.doi.org/10.1016/j.erss.2016.10.006

22. Curtis, S., Gesler, W., Smith, G. and Washburn, S. (2000) 'Approaches to Sampling and Case Study Selection in Qualitative Research: Examples in the Geography of Health' In: Social Science and Medicine 50 (7-8) 1001 - 1014

23. Davies, R. (1984) 'The Sizewell B Nuclear Inquiry: An Analysis of Public Participation in Decisionmaking about Nuclear Power' In: Science, Technology and Human Values 9 (3) $21-32$ 
24. Day, R., Walker, G. and Simcock, N. (2016) 'Conceptualising energy use and energy poverty using a capabilities framework' In: Energy Policy 93 (June 2016) 255 - 264

25. DECC (2013) UK Renewable Energy Roadmap Update 2013 London: Crown Copyright

26. DECC (2014) Community Energy Strategy: Full Report London: Crown Copyright

27. Demski, C., Butler, C., Parkhill, K. A., Spence, A. and Pidgeon, N. F. (2015) 'Public Values for Energy System Change' In: Global Environmental Change 34 (September 2015) 59 69

28. Devine-Wright, P. (2006) 'Energy Citizenship: Psychological Aspects of Evolution in Sustainable Energy Technologies' In: Murphy, J. (ed) Governing Technology for Sustainability London: Earthscan

29. Devine-Wright, P. (2009) 'Rethinking NIMBYism: The Role of Place Attachment and Place Identity in Explaining Place-protective Action' In: Journal of Community and Applied Social Psychology 19 (6) $426-441$

30. Devine-Wright, P. and Wiersma, B. (2013) 'Opening up the "Local" to Analysis: Exploring the Spatiality of UK Urban Decentralised Energy Initiatives' In: Local Environment 18 (10) $1099-1116$

31. Dunkley, R. A. and Franklin, A. (2017) 'Failing Better: The Stochastic Art of Evaluating Community-led Environmental Action Programs' In: Evaluation and Program Planning 60 (February) $112-122$

32. Dunn, P. D. (1978) Appropriate Technology: Technology with a Human Face London: Macmillan

33. Eames, M. and Hunt, M. (2013) 'Energy Justice in Sustainability Transitions Research' In: Bickerstaff, K., Walker, G. and Bulkeley, H. (eds) Energy Justice in a Changing Climate: Social Equity and Low-Carbon Energy London: Zed Books

34. Eden, S. (2017) Environmental Publics London: Routledge

35. Fuller, S. and Bulkeley, H. (2013) 'Energy Justice and the Low-Carbon Transition: Assessing Low-Carbon Community Programmes in the UK' In: Bickerstaff, K., Walker, G. and Bulkeley, H. (eds) Energy Justice in a Changing Climate: Social Equity and LowCarbon Energy London: Zed Books

36. Fuller, S. and McCauley, D. (2016) 'Framing Energy Justice: Perspectives from Activism and Advocacy' In: Energy Research and Social Science 11 (2016) 1 - 8

37. Geels, F. W. (2002) 'Technological Transitions as Evolutionary Reconfiguration Processes: A Multi-Level Perspective and a Case Study' In: Research Policy 31(8-9) 1257 - 1274 
38. Goldthau, A. and Sovacool, B. (2012) 'The Uniqueness of the Energy Security, Justice, and Governance Problem' In: Energy Policy 41 (2012) 232 - 240

39. Grossmann, M. and Creamer, E. (2017) 'Assessing Diversity and Inclusivity within the Transition movement: An Urban case Study' In: Environmental Politics 26 (1) 161 - 182

40. Gunningham, N. (2013) 'Managing the Energy Trilemma: The Case of Indonesia' In: Energy Policy 54 (March 2013) $184-193$

41. Hall, S. M. (2013) 'Energy Justice and Ethical Consumption: Comparison, Synthesis and Lesson Drawing' In: Local Environment 18 (4) $422-437$

42. Hammond, G. P. and Pearson, P. J. G. (2013) 'Challenges of the Transition to a Low Carbon, more Electric Future: From Here to 2050' In: Energy Policy 52 (January 2013) 1 9

43. Hards, S. K. (2013) 'Status, Stigma and Energy Practices in the Home' In: Local Environment 18 (4) $438-454$

44. Hargreaves, T., Hielscher, S., Seyfang, G. and Smith, A. (2013) 'Grassroots Innovations in Community Energy: The Role of Intermediaries in Niche Development' In: Global Environmental Change 23 (5) $868-880$

45. Heiskanen, E., Johnson, M., Robinson, S., Vadovics, E. and Saastamoinen, M. (2010) 'Low-carbon Communities as a Context for Individual Behaviour Change' In: Energy Policy 38 (12) $7586-7595$

46. Heffron, R. and McCauley, D. (2014) 'Achieving Sustainable Supply Chains through Energy Justice' In: Applied Energy $123435-437$

47. Heffron, R., McCauley, D. and Sovacool, B. K. (2015) 'Resolving Society's Energy Trilemma through the Energy Justice Metric' In: Energy Policy $87168-176$

48. Heller, M. (2003) 'Globalization, the new economy, and the commodification of language and identity' In: Journal of Sociolinguistics 7 (4) $473-492$

49. Hielscher, S., Seyfang, G. and Smith, A. (2011) Community Innovation for Sustainable Energy [Online] Available:

http://sro.sussex.ac.uk/53351/1/HielscherSmithWorkingPaperCSERGE.pdf [Accessed 29 November 2016]

50. Hoffman, S. M. and High-Pippert, A. (2010) 'From Private Lives to Collective Action: Recruitment and Participation Incentives for a Community Energy Program' In: Energy Policy 38 (12) $7567-7574$

51. Honneth, A. (1995) The Struggle for Recognition: The Moral Grammar of Social Conflicts Cambridge, MA: The MIT Press 
52. Hopkins, R. (2008) The Transition Handbook: From Oil Dependence to Local Resilience Totnes: Green Books

53. Jenkins, K., Heffron, R. and McCauley, D. (2016a) 'The Political Economy of Energy Justice: A Nuclear Energy Perspective' In: Van de Graaf, T., Sovacool, B. K., Ghosh, A., Kern, F. and Klare, M. T. (eds) (2016) The Palgrave Handbook of the International Political Economy of Energy London: Palgrave Macmillan

54. Jenkins, K., McCauley, D. and Forman, A. (2017) 'Energy Justice: A Policy Approach' In: Energy Policy 105 (June 2017) 631 - 634

55. Jenkins, K., McCauley, D., Heffron, R., Stephan, H. and Rehner, R. (2016b) 'Energy Justice: A Conceptual Review' In: Energy Research and Social Science 11 (2016) 174 182

56. Jeong, Y., Simcock, N., and Walker, G. (2012) 'Making power differently: Exploring the motives and meanings of community renewable energy developments in cases from the UK and South Korea' In: Davies, A. (ed) Enterprising Communities: Grassroots Sustainability Innovations Bingley: Emerald Group Publishing

57. Johnson, V. C. A. and Hall, S. (2014) 'Community Energy and Equity: The Distributional Implications of a Transition to a Decentralised Energy System' In: People, Place and Policy 8 (3) $149-167$

58. Jones, B. R., Sovacool, B. K. and Sidortsov, R. V. (2015) 'Making the Ethical and Philosophical Case for "Energy Justice"' In: Environmental Ethics 37 (2) $145-168$

59. Kemmis, S. and McTaggart, R. (2005) 'Participative Action Research: Communicative Action and the Public Sphere' In: Denzin, N. K. and Lincoln, Y. S. (eds) The SAGE Handbook of Qualitative Research (3rd Ed) London: Sage

60. Kraft, M. E. and Clary, B. B. (1991) 'Citizen participation and the nimby syndrome: Fleetwood $2 \mathrm{f}$ Public response to radioactive waste disposal' In: Western Political Quarterly 44 (2) $299-328$

61. Liddell, C., Morris, C., Gray, B., Czerwinska, A. And Thomas, B. (2016) 'Excess winter mortality associated with Alzheimer's Disease and related dementias in the UK: A case for energy justice' In: Energy Research and Social Science 11 (2016) $256-262$

62. Lovins, A. B. (1977) Soft Energy Paths: Towards a Durable Peace Harmondsworth: Penguin

63. Malhotra, P. (2006) 'Management of Community-based Energy Interventions in Rural Areas of India: Issues and Perspectives' In: Sustainable Development 14 (1) $33-45$ 
64. Markantoni, M. (2016) 'Low Carbon Governance: Mobilizing Community Energy through Top-down Support' In: Environmental Policy and Governance 26 (3) $155-169$

65. Marres, N. (2007) 'The Issues Deserve more Credit: Pragmatist Contributions to the Study of Public Involvement in Controversy' In: Social Studies of Science 37 (5) $759-780$

66. Marvin, S. and Guy, S. (1997) 'Creating Myths rather than Sustainability: The Transition Fallacies of the New Localism' In: Local Environment 2(3) $311-318$

67. McCauley, D., Heffron, R., Hannes, S. and Jenkins, K. (2013) 'Advancing Energy Justice: The Triumvirate of Tenets' In: International Energy Law Review 32 (3) $107-110$

68. McCauley, D., Heffron, R., Pavlenko, M., Rehner, R. and Holmes, R. (2016) 'Energy Justice in the Arctic: Implications for Energy Infrastructural Development in the Arctic' In: Energy Research and Social Science 16 (2016) $141-146$

69. Meadowcroft, J. (2009) 'What about the Politics? Sustainable Development, Transition Management, and Long Term Energy Transitions' In: Policy Sciences 42 (4) $323-340$

70. Meadows, D. (2009) Thinking in Systems: A Primer London: Earthscan

71. Middlemiss, L. and Parrish, B. D. (2010) 'Building Capacity for Low-Carbon Communities' In: Energy Policy 38 (12) $7559-7566$

72. Miles, M. and Huberman, A. (1994) Qualitative Data Analysis London: Sage

73. Misa, T, J. (1994) 'Retrieving Sociotechnical Change from Technological Determinism' In: Smith, M. R. and Marx, L. (eds) Does Technology Drive History? The Dilemma of Technological Determinism Cambridge, Massachusetts: The MIT Press

74. Morton, A., Airoldi, M. and Phillips, L. D. (2009) 'Nuclear Risk Management on Stage: A Decision Analysis Perspective on the UK's Committee on Radioactive Waste Management' In: Risk Analysis 29 (5) $764-779$

75. Newell, P. and Mulvaney, D. (2013) 'The Political Economy of the "Just Transition"' In: The Geographical Journal 179 (2) $132-140$

76. Nicholson, N. (1995) 'Enactment' In: Nicholson, N. (ed) Blackwell Encyclopedic Dictionary of Organizational Behaviour Cambridge, MA: Blackwell

77. Ofgem (2015) An Introduction to Licence Lite [Online] Available: https://www.ofgem.gov.uk/sites/default/files/docs/2015/04/482 an introduction to li cence lite factsheet web 0.pdf [Last Accessed: 29 April 2017]

78. O'Leary, Z. (2004) The Essential Guide to Doing Research London: Sage 
79. Parkhill, K. A., Shirani, F., Butler, C., Henwood, K. L., Groves, C. and Pidgeon, N. F. (2015) "We are a community [but] that takes a certain amount of energy": Exploring shared visions, social action, and resilience in place-based community-led energy initiatives' In: Environmental Science and Policy 53 (Part A) 60-69

80. Ragin, C. C. (1992) "Casing" and the Process of Social Inquiry' In: Ragin, C. C. and Becker, H. S. (eds) What is a Case? Exploring the Foundations of Social Inquiry Cambridge: Cambridge University Press

81. Sayer, A. (1992) Method in Social Science: A Realist Approach 2nd Ed. Abingdon: Routledge

82. Schlosberg, D. (2004) 'Reconceiving Environmental Justice: Global Movements and Political Theories' In: Environmental Politics 13 (3) 517 - 540

83. Schlosberg, D. (2007) Defining Environmental Justice: Theories, Movements, and Nature Oxford: Oxford University Press

84. Schlosberg, D. and Collins, L. B. (2014) 'From environmental to climate justice: climate change and the discourse of environmental justice' In: Wiley Interdisciplinary Review: Climate Change 5 (3) $359-374$

85. Schumacher, E. F. (1974) Small is Beautiful: A Study of Economics as if People Mattered London: Sphere

86. Seyfang, G. and Haxeltine, A. (2012) 'Growing Grassroots Innovations: Exploring the Role of Community-based Initiatives in Governing Sustainable Energy Transitions' In: Environment and Planning C 30 (3) $381-400$

87. Seyfang, G., Hielscher, S., Hargreaves, T., Martiskainen, M. and Smith, A. (2014) 'A Grassroots Sustainable Energy Niche? Reflections on Community Energy in the UK' In: Environmental Innovation and Societal Transitions 13 (December 2014) 21 - 44

88. Shirani, F., Butler, C., Henwood, K., Parkhill, K. and Pidgeon, N. (2013) 'Disconnected Futures: Exploring Notions of Ethical Responsibility in Energy Practices' In: Local Environment 18 (4) $455-468$

89. Simcock, N. (2014) 'Exploring how stakeholders in two community wind projects use a "those affected" principle to evaluate the fairness of each project's spatial boundary' In: Local Environment 19 (3) $241-258$

90. Simcock, N. (2016) 'Procedural Justice and the Implementation of Community Wind Energy Projects: A Case Study from South Yorkshire, UK' In: Land Use Policy 59 467-477

91. Simcock, N. and Mullen, C. (2016) 'Energy Demand for Everyday Mobility and Domestic Life: Exploring the Justice Implications' In: Energy Research and Social Science 18 (2016) $1-6$ 
92. Smith, A. (2012) 'Civil Society in Sustainable Energy Transitions' In: Verbong, G. and Loorbach, D. (eds) Governing the Energy Transition: Reality, Illusion or Necessity? Abingdon: Routledge

93. Smith, J. M. (2016) 'Climate Change Justice and Corporate Responsibility' In: Journal of Energy and Natural Resources Law 34 (1) $70-74$

94. Sovacool, B. K. (2014) 'What are we doing here? Analysing 15 Years of Energy Scholarship and Proposing a Social Science Research Agenda' In: Energy Research and Social Science 1 (2014) 1 -29

95. Sovacool, B. K. (2015) 'Fuel poverty, affordability, and energy justice in England: Policy insights from the Warm Front Program' In: Energy 93 (1) $361-371$

96. Sovacool, B. K. and Dworkin, M. H. (2014) Global Energy Justice: Problems, Principles and Practices Cambridge: Cambridge University Press

97. Sovacool, B. K., Sidortsov, R. V. and Jones, B. R. (2014) Energy Security, Equality, and Justice London: Routledge

98. Sovacool, B. K. and Dworkin, M. H. (2015) 'Energy Justice: Conceptual Insights and Practical Applications' In: Applied Energy 142 (2015) 435 - 444

99. Sovacool, B. K., Heffron, R. J., McCauley, D. and Goldthau, A. (2016) 'Energy Decisions reframed as Justice and Ethical Concerns' In: Nature Energy 1 (5) 16024

100. Sovacool, B. K. and Scarpaci, J. (2016) 'Energy justice and the contested petroleum politics of stranded assets: Policy insights from the Yasuní-ITT Initiative in Ecuador' In: Energy Policy 95 (August 2016) 158-171

101. Späth, P. and Rohracher, H. (2012) 'Local Demonstrations for Global Transitions Dynamics across Governance Levels Fostering Socio-technical Regime Change towards Sustainability' In: European Planning Studies 20 (3) $461-479$

102. Strachan, P., Cowell, R., Ellis, G., Sherry-Brennan, F. and Toke, D. (2015) ‘Promoting Community Energy in a Corporate Energy World' In: Sustainable Development 23 (2) 96 $-109$

103. Van Veelen, B. (2017) 'Making Sense of the Scottish Community Energy Sector - An Organising Typology' In: Scottish Geographical Journal 133 (1) 1 - 20

104. Van Veelen, B. and Haggett, C. (2016) 'Uncommon Ground: The Role of Different Place Attachments in Explaining Community Renewable Energy Projects' In: Sociologia Ruralis doi:10.1111/soru.12128 
105. Walker, G. (2008) 'What are the Barriers and Incentives for Community-owned means of Energy Production and Use?' In: Energy Policy 36 (12) $4401-4405$

106. Walker, G. (2009) 'Beyond Distribution and Proximity: Exploring the Multiple Spatialities of Environmental Justice' In: Antipode 41 (4) 614-636

107. Walker, G. (2012) Environmental Justice: Concepts, Evidence and Politics Abingdon: Routledge

108. Walker, G. and Cass, N. (2007) 'Carbon Reduction, "The Public" and Renewable Energy: Engaging with Socio-technical Configurations' In: Area 39 (40) $459-469$

109. Walker, G., Hunter, S., Devine-Wright, P., Evans, B. and Fay, H. (2007) 'Harnessing Community Energies: Explaining and Evaluating Community-based Localism in Renewable Energy Policy in the UK' In: Global Environmental Politics 7 (2) $64-82$

110. Walker, G. and Devine-Wright, P. (2008) 'Community Renewable Energy: What Should it Mean?' In: Energy Policy 36 (2) 497 - 500

111. Walker, G., Simcock, N. and Day, R. (2016) 'Necessary Energy Uses and a Minimum Standard of Living in the United Kingdom: Energy Justice or Escalating Expectations?' In: Energy Research and Social Science 18 (August 2016) 129-138

112. Wiersma, B. and Devine-Wright, P. (2014) 'Decentralising Energy: Comparing the Drivers and Influencers of Projects led by Public, Private, Community and Third Sector Actors' In: Contemporary Social Science 9 (4) 456-470

113. Weick, K. E. (2009) 'Enacting an Environment: The Infrastructure of Organizing' In: Weick, K. E. (ed) Making Sense of the Organization: The Impermanent Organization Chichester: John Wiley and Sons Ltd

114. Welsh Government (2015) Well-being of Future Generations (Wales) Act 2015: The Essentials Cardiff: Welsh Government

115. Welsh Government (2016a) Final Evaluation of the Ynni'r Fro Renewable Energy Support Scheme Cardiff: Welsh Government

116. Welsh Government (2016b) How to Measure a Nation's Progress? National Indicators for Wales Cardiff: Welsh Government

117. World Energy Council (2015) World Energy Trilemma: Priority Actions on Climate Change and how to Balance the Trilemma London: World Energy Council

118. Wynne, B. (1982) Rationality and Ritual: Participation and Exclusion in Nuclear Decision-making Abingdon: Earthscan 
119. Yenetti, K. and Day, R. (2016) 'Distributional Justice in Solar Energy Implementation in India: The Case of Charanka Solar Park' In: Journal of Rural Studies 46 (2016) 35 - 46

120. Yenetti, K., Day, R. and Golubchikov, O. (2016) 'Spatial justice and the land politics of renewables: Dispossessing vulnerable communities through solar energy mega-projects' In: Geoforum 76 (November 2016) $90-99$ 